Egyptian Journal of Aquatic Biology \& Fisheries

Zoology Department, Faculty of Science,

Ain Shams University, Cairo, Egypt.

ISSN $1110-6131$

Vol. 23(2): 433 - 441 (2019)

www.ejabf.journals.ekb.eg

\title{
Morphometric and Meristic features and Length-Weight Relationship as indicators of quality of Brycinus macrolepidotus in Lower River Ogun, Nigeria
}

\author{
Adeosun F. Idowu ${ }^{* 1}$, Idowu A. Adedoyin ${ }^{1}$, Oghenochuko M. Titilayo \\ Oghenebrorhie $^{1,2}$, Adebowale A. Quddus ${ }^{1}$ and Adekoya O. Micheal ${ }^{1}$
}

1- Department of Aquaculture and Fisheries Management, Federal University of Agriculture, Abeokuta, Nigeria

2- Animal Science Program, Department of Agricultural Science, Landmark University, Omu-Aran, Nigeria

*Corresponding aurthor: adeosunfi@yahoo.com

\author{
ARTICLE INFO \\ Article History: \\ Received: March 23, 2019 \\ Accepted: May 30, 2019 \\ Online: June 2019 \\ Keywords: \\ Brycinus macrolepidotus \\ River Ogun \\ Nigeria \\ Morphometry \\ Meristic features
}

\begin{abstract}
One Hundred And Eighty samples of True big-scale fish (Brycinus macrolepidotus Valenciennes, 1850) were collected bi-monthly from June - November, 2017, from River Ogun, Nigeria. Total length and body weight of all samples measured and samples were grouped based on length into sizes: juveniles $(10-14.9 \mathrm{~cm})$, sub-adults $(15.1-19.9 \mathrm{~cm})$, and adults $(20.2-26.3 \mathrm{~cm})$. Significant differences $(\mathrm{p}<0.05)$ were observed in the meristic characters in all the groups. Dorsal fin ray ranged from $7-9$, pelvic fin ray 8-12, caudal fin ray $18-24$, pectoral fin ray $7-12$, anal ray $12-14$ and dorsal spine 0-9 through the wet and dry season for all sizes. LengthWeight relationship for juveniles, sub-adult and adult sizes showed ' $a$ ', 'b' and ' $r$ ' values for juveniles as $-0.82,2.17$ and 0.85 , sub-adult as -0.38 , 1.82 and 0.90 and adult as $0.44,1.03$ and 0.78 respectively. Mean condition factor recorded was $1.16 \pm 0.15,1.39 \pm 0.13$, and $2.17 \pm 0.59$ for adult, sub-adult and juvenile respectively. Conclusively, B. macrolepidotus in this aquatic ecosystem could be in a good environment and quality as condition factor of all sizes were above 1 .
\end{abstract}

\section{INTRODUCTION}

Brycinus macrolepidotus, the True big-scale tetra belongs to the family Alestidae of the order Characiformes (Valenciennes). It is easily identified by its dark bands or stripes found on their bodies and are very prominent in adult forms. The Brycinus species are common in fresh water bodies having low salinity; they are potamodromous and are more commonly found in rivers than in lakes (Olurin and Aderibigbe, 2006). It is as an omnivore and feed on both plants e.g. vegetation, debris, etc and animals matter (e.g. insects, crustaceans and small fishes) in the environment in which it is found (Ikomi and Sikoki, 2003). The quality of a fish species in the aquatic habitat is very vital in determining the condition of that resource.

Condition factor is also a useful index for monitoring of feeding intensity, age, growth rates and quality of fish (Ndimele et al., 2010). It is strongly influenced by both biotic and a biotic environmental conditions and can be used as an index to assess the status of the aquatic ecosystem in which fish live (Anene, 2005) 
B. macrolepidotus is a species of high economic importance in this part of the world. Many researches have been done on its biology, population size, etc in different water bodies; little has been done on its condition and quality. The quality and condition of the species is vital to policy makers, fisheries managers, fish farmers and resource users as it sheds light on the state of the water body, potential for fish population decrease and enactment of policy to guide resource users, but there is still not enough information on $B$. macrolepidotus as compared with other fresh water fish species in Nigeria waters.

It is on this premise that the present study was designed to analyze the morphometric and meristic features and Length-weight relationship as indicators of the quality of the fish, B. macrolepidotus in Lower Ogun River, Akomoje, Ogun State, Nigeria.

\section{MATERIALS AND METHODS}

\section{Description of the study area}

The study was carried out at the lower Ogun River, Akomoje, Abeokuta, Ogun State. Ogun River (Figure 1) is located in Abeokuta North Local Government of Ogun State. It is one of the major rivers in Southwestern Nigeria with a total area of $22.4 \mathrm{~km}^{2}$ and a fairly large flow of about $393 \mathrm{~m}^{3} / \mathrm{s}$ during the wet season (Oketola et al., 2006). It has coordinates of $3^{\circ} 28^{\prime} \mathrm{E}$ and $8^{\circ} 41^{\prime} \mathrm{N}$ from its source in Oyo state to $3^{\circ} 25^{\prime} \mathrm{E}$ and $6^{\circ} 35^{\prime} \mathrm{N}$ in Lagos where it enters the Lagos lagoon (Ayoade et al., 2004).

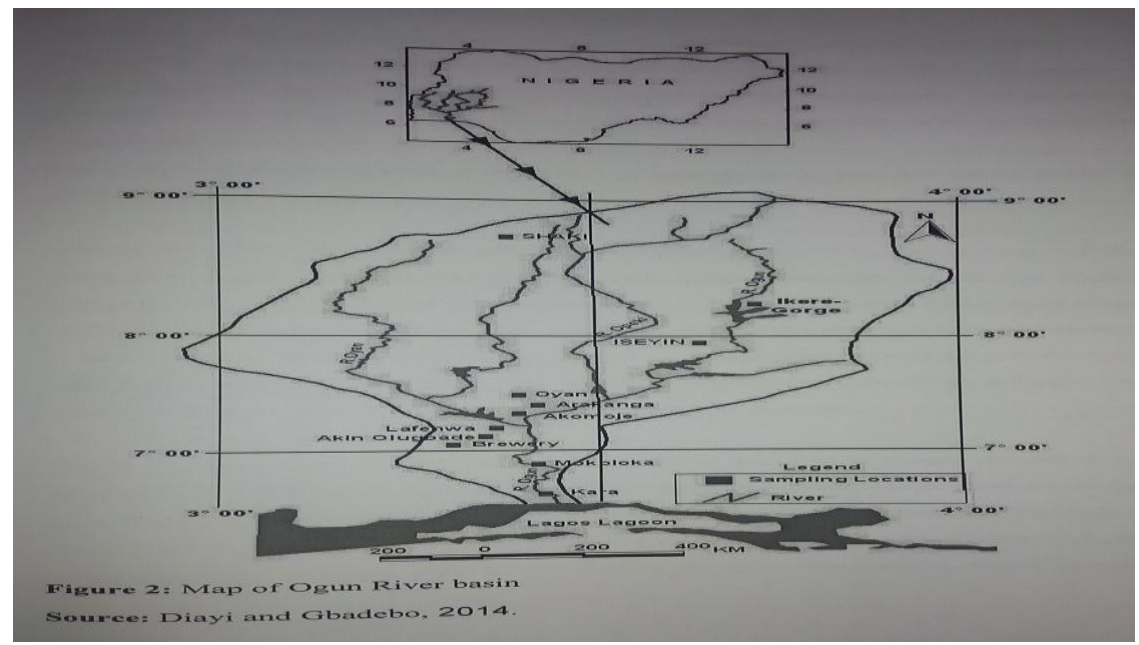

Fig. 1: Map of River Ogun

Source: Diayi and Gbadebo (2014)

\section{Collection of fish samples}

Collection of 180 fresh fish samples of $B$. macrolepidotus was done bi-monthly for a period of six months (June - November, 2017) from catches landed by artisanal fishermen marking the peak of the rains and onset dry months which spans their maturation to spawning and period after spawning (Paugy, 2002). The fish were caught using cast nets of mesh sizes: $12-22 \mathrm{~mm}$ and gill nets of mesh sizes 20$45 \mathrm{~mm}$. The fish were transported in ice chest to the laboratory of the Aquaculture and Fisheries Management Department, Federal University of Agriculture Abeokuta, Ogun State, for measurement. They were identified to species level using the fish catalogue of FAO [Food and Agricultural Organization (FAO, 1990)].

\section{Laboratory examination of the fish specimens}

In the laboratory, the fish were examined, washed properly and using clean towel to mop off water from the surface of the specimen. Biometrics including 
standard length (SL), total length (TL) and body weight (BWt) were measured landing site using a calibrated plastic board and a sensitive weighing balance (CAMRY, Model no EK5350) (Moruf and Lawal-Are, 2015) to the nearest $0.1 \mathrm{~cm}$ and $0.1 \mathrm{~g}$. Other characters measured were body depth (BD), caudal peduncle depth (CD), caudal peduncle length (CL), Head length (HL), head depth (HD), snout length (SL), Dorsal fin length (LD), pelvic fin length (Lpel), anal fin length (LA) Eye depth (ED). While meristic features counted include number of scales on the lateral line (SLL), dorsal fin rays $\left(D_{R}\right)$, anal fin rays $\left(A_{R}\right)$, pectoral fin rays $(R p e c)$, Pelvic fin rays (Rpel), caudal fin rays $\left(C_{R}\right)$ and dorsal fin spines (Ds). All the measurements and counts were made on the left side of the fish. Using only their total length, fish samples were then grouped into different sizes (juveniles, sub- adults, and adults) for further analysis.

Experimental protocols carried out on test animals were in line with the internationally accepted principles for the laboratory animal usage and were approved by Ethics Committee on the Laboratory Animal Use of the College of Veterinary Medicine of the Federal University of Agriculture, Abeokuta.

\section{Length-weight relationship}

The length-weight equation; $\mathrm{W}=\mathrm{aL}^{\mathrm{b}}$ as described by Ricker (Panase and Mengumphan, 2015) was used to establish the length-weight relationship of the species measured,

Where;

$\mathrm{W}=$ total body weight in grams $(\mathrm{g})$,

$\mathrm{L}=$ total length in centimeters $(\mathrm{cm})$,

$\mathrm{a}=$ scaling constant determined empirically

$\mathrm{b}=$ growth coefficient.

Constant 'a' represents the point at which the regression line intercepts the yaxis and ' $b$ ' the slope of the regression line.

The equation above was logarithmically transformed to a general linear equation of a straight line (Abdul et al., 2016).

$$
\mathbf{Y}=\mathbf{a}+\mathbf{b X}
$$

Where $\mathrm{Y}=$ dependent variable

$\mathrm{X}=$ independent variable

$\mathrm{a}=\mathrm{y}-$ intercept

$\mathrm{b}=$ slope

as:

$$
\log W=\log a+b^{*} \log L
$$

Where $\log \mathrm{W}=\log$ of weight of the fish

$\log \mathrm{L}=\log$ of length of the fish

Loga $=$ y-intercept

$$
\mathrm{b}=\text { slope }
$$

After logarithmic transformation of this relation $(\log a+b \log L)$, parameters ' $a$ ' and ' $b$ ' was determined via least squares linear regression according to Zar (2010). The value of ' $b$ ' gives information on the kind of growth of fish: The growth is isometric if $b=3$ and the growth is allometric if $b \neq 3$ (negative allometric if $b<3$ and positive allometric if $\mathrm{b}>3$ ) as described by Le Cren (Abdul et al., 2010).

The length-weight equation was estimated for juvenile, sub-adult and adult sizes of B. macrolepidotus. 


\section{Condition Factor}

The condition factor $(\mathrm{k})$ which defines the well-being of the fish was calculated. It is a useful index for monitoring feeding intensity, age, and growth rates. Fish in good condition have higher condition factor value than those in poor condition. ' $\mathrm{k}$ ' was determined as described by Bagenal (Abdul et al., 2010)

$$
\begin{aligned}
\mathrm{k}=\frac{\mathrm{W} \times 100}{\mathrm{~L}^{3}} \quad \text { Where: } \mathrm{k} & =\text { Condition factor } \\
\mathrm{W} & =\text { total weight of fish in grams } \\
\mathrm{L} & =\text { total length of fish in centimeters }
\end{aligned}
$$

\section{Data analysis}

Statistical Package for Social Sciences (SPSS) version 20 was used for the analysis of data obtained. Descriptive (Tables) and correlation statistics were used to depict the result of the study.

\section{RESULTS}

\section{Morphometric and Meristic characteristics}

Results of morphometric features divided the experimental fish into three categories (juvenile, sub-adult and adult) comprising 60 fish samples each (Table 1). The mean of the meristic features of three varying samples were compared to each other in Table 2. There was significant differences $(\mathrm{p}<0.05)$ in all the meristic

\begin{tabular}{|c|c|c|c|}
\hline Traits & $\begin{array}{c}\text { Mean } \pm \text { SD } \\
(\text { Juveniles) }\end{array}$ & $\begin{array}{l}\text { Mean } \pm \text { SD } \\
\text { (Sub-adults) }\end{array}$ & $\begin{array}{l}\text { Mean } \pm \text { SD } \\
\text { (adults) }\end{array}$ \\
\hline Total Length & $12.17 \pm 1.68$ & $17.91 \pm 1.15$ & $22.87 \pm 1.44$ \\
\hline Standard Length & $10.26 \pm 1.42$ & $15.14 \pm 1.13$ & $20.19 \pm 1.58$ \\
\hline Body Depth & $2.67 \pm 0.37$ & $4.23 \pm 0.46$ & $5.26 \pm 0.55$ \\
\hline Head Length & $2.03 \pm 0.44$ & $3.29 \pm 0.24$ & $3.69 \pm 0.36$ \\
\hline Head Depth & $1.63 \pm 0.23$ & $2.25 \pm 0.37$ & $3.21 \pm 0.46$ \\
\hline Snout Length & $0.77 \pm 0.13$ & $1.14 \pm 0.16$ & $1.22 \pm 0.12$ \\
\hline Dorsal fin Length & $0.94 \pm 0.22$ & $1.45 \pm 0.15$ & $1.69 \pm 0.23$ \\
\hline Anal Length & $1.29 \pm 0.32$ & $2.14 \pm 0.16$ & $2.65 \pm 0.30$ \\
\hline Eye Diameter & $0.80 \pm 0.08$ & $0.91 \pm 0.10$ & $1.00 \pm 0.00$ \\
\hline Body Weight & $36.63 \pm 6.20$ & $79.97 \pm 10.23$ & $139.70 \pm 25.13$ \\
\hline Caudal Peduncle Length & $1.43 \pm 0.43$ & $1.92 \pm 0.17$ & $2.38 \pm 0.21$ \\
\hline Caudal Peduncle Depth & $1.06 \pm 0.19$ & $1.55 \pm 0.14$ & $2.06 \pm 0.17 \mathrm{z}$ \\
\hline Pelvic fin Length & $0.58 \pm 0.15$ & $0.77 \pm 0.14$ & $0.89 \pm 0.12$ \\
\hline Lateral line Scales & $22.55 \pm 1.02$ & $23.47 \pm 0.88$ & $22.90 \pm 0.85$ \\
\hline Dorsal fin ray & $7.4 \pm 0.49$ & $7.72 \pm 0.52$ & $7.46 \pm 0.56$ \\
\hline Anal fin ray & $12.6 \pm 0.61$ & $13.2 \pm 0.75$ & $13.52 \pm 0.59$ \\
\hline Pectoral fin ray & $9.68 \pm 0.72$ & $9.81 \pm 1.65$ & $7.8 \pm 0.40$ \\
\hline Caudal fin ray & $21.08 \pm 1.27$ & $21.26 \pm 1.93$ & $21.23 \pm 1.65$ \\
\hline Pelvic fin ray & $9.05 \pm 0.59$ & $9.72 \pm 0.68$ & $10.26 \pm 0.68$ \\
\hline Dorsal fin spine & $0.63 \pm 0.55$ & $8.68 \pm 0.46$ & $8.56 \pm 0.50$ \\
\hline
\end{tabular}
characters for the three groups.

Table 1: Mean morphometric and meristic values of different sizes of B.m acrolepidotus

Table 2: Meristic character for the adult, sub-adult and juvenile sizes of $\boldsymbol{B}$. macrolepidotus

\begin{tabular}{llll}
\hline Characteristics & Adult & Sub-adullt & Juvenile \\
Dorsal fin ray & $7.46 \pm 0.56^{\mathrm{a}}$ & $7.72 \pm 0.52^{\mathrm{b}}$ & $7.4 \pm 0.49^{\mathrm{a}}$ \\
Anal fin ray & $13.52 \pm 0.59^{\mathrm{a}}$ & $13.2 \pm 0.75^{\mathrm{a}}$ & $12.6 \pm 0.61^{\mathrm{b}}$ \\
Pectoral fin ray & $7.8 \pm 0.40^{\mathrm{a}}$ & $9.81 \pm 1.65^{\mathrm{b}}$ & $9.68 \pm 0.72^{\mathrm{c}}$ \\
Caudal fin ray & $21.23 \pm 1.65^{\mathrm{a}}$ & $21.26 \pm 1.93^{\mathrm{a}}$ & $21.08 \pm 1.27^{\mathrm{a}}$ \\
Pelvic fin ray & $10.26 \pm 0.68^{\mathrm{a}}$ & $9.72 \pm 0.68^{\mathrm{a}}$ & $9.05 \pm 0.59^{\mathrm{b}}$ \\
Dorsal fin spine & $8.56 \pm 0.50^{\mathrm{a}}$ & $8.68 \pm 0.46^{\mathrm{a}}$ & $0.63 \pm 0.55^{\mathrm{b}}$ \\
\hline \multicolumn{2}{l}{ Mean values in the same row with the same superscripts are not significantly different $(\mathrm{P}>0.05)$ from each other }
\end{tabular}


Correlation matrix of morphometric characters of $B$. macrolepidotus

Correlation matrix of the morphometric characters are shown in Table 3a-c. Eye diameter (ED) had no correlation with all other traits in the adult samples.

Table 3a: Correlation matrix of morphometric characters of B. macrolepidotus (Adult)

\begin{tabular}{llllllllllllll}
\hline Characters & TL & SL & BD & HL & HD & SnL & LD & LA & LP & CL & CD & ED & BW \\
\hline L & 1 & & & & & & & & & & & & \\
SL & 0.869 & 1 & & & & & & & & & & \\
BD & 0.741 & 0.473 & 1 & & & & & & & & & \\
HL & 0.395 & 0.472 & 0.243 & 1 & & & & & & & & \\
HD & 0.198 & 0.467 & -0.271 & 0.490 & 1 & & & & & & & \\
SnL & 0.685 & 0.638 & 0.590 & 0.136 & 0.149 & 1 & & & & & & \\
LD & 0.688 & 0.442 & 0.686 & 0.279 & -0.133 & 0.492 & 1 & & & & & \\
LA & 0.679 & 0.542 & 0.575 & 0.322 & 0.051 & 0.518 & 0.696 & 1 & & & & \\
LP & 0.721 & 0.628 & 0.636 & 0.495 & 0.125 & 0.550 & 0.732 & 0.730 & 1 & & & \\
CL & 0.222 & 0.045 & 0.408 & 0.129 & -0.082 & 0.479 & 0.242 & 0.127 & 0.107 & 1 & & & \\
CD & 0.294 & 0.295 & 0.198 & 0.514 & 0.390 & 0.297 & 0.329 & 0.158 & 0.227 & 0.486 & 1 & & \\
ED & - & - & - & - & - & - & - & - & - & - & - & 1 & \\
BW & 0.750 & 0.596 & 0.725 & 0.577 & 0.163 & 0.503 & 0.686 & 0.599 & 0.727 & 0.363 & 0.409 & - & 1 \\
\hline
\end{tabular}

Table 3b: Correlation matrix of morphometric characters of B. macrolepidotus (Sub-Adult)

\begin{tabular}{|c|c|c|c|c|c|c|c|c|c|c|c|c|c|}
\hline Characters & TL & SL & BD & HL & $\mathrm{HD}$ & $\mathrm{SnL}$ & LD & LA & LP & CL & $\mathrm{CD}$ & ED & BW \\
\hline TL & 1 & & & & & & & & & & & & \\
\hline SL & 0.936 & 1 & & & & & & & & & & & \\
\hline $\mathrm{BD}$ & 0.621 & 0.517 & 1 & & & & & & & & & & \\
\hline HL & 0.759 & 0.823 & 0.487 & 1 & & & & & & & & & \\
\hline $\mathrm{HD}$ & 0.344 & 0.427 & -0.381 & 0.325 & 1 & & & & & & & & \\
\hline SnL & 0.469 & 0.396 & 0.534 & 0.328 & -0.005 & 1 & & & & & & & \\
\hline LD & 0.574 & 0.542 & 0.216 & 0.485 & 0.461 & 0.268 & 1 & & & & & & \\
\hline LA & 0.759 & 0.724 & 0.336 & 0.580 & 0.495 & 0.382 & 0.668 & 1 & & & & & \\
\hline LP & 0.380 & 0.406 & -0.062 & 0.248 & 0.548 & -0.066 & 0.480 & 0.498 & 1 & & & & \\
\hline $\mathrm{CL}$ & 0.721 & 0.701 & 0.560 & 0.582 & 0.205 & 0.416 & 0.582 & 0.535 & 0.324 & 1 & & & \\
\hline CD & 0.649 & 0.616 & 0.579 & 0.475 & 0.047 & 0.393 & 0.376 & 0.470 & 0.203 & 0.485 & 1 & & \\
\hline ED & 0.475 & 0.451 & -0.070 & 0.330 & 0.667 & 0.151 & 0.378 & 0.592 & 0.400 & 0.317 & 0.312 & 1 & \\
\hline BW & 0.889 & 0.813 & 0.632 & 0.623 & 0.203 & 0.488 & 0.440 & 0.715 & 0.300 & 0.611 & 0.577 & 0.400 & 1 \\
\hline
\end{tabular}

The closer the r-value to positive $1(+1)$ the stronger the relationship between the features

Table 3c: Correlation matrix of morphometric characters of B. macrolepidotus (Juvenile)

\begin{tabular}{llllllllllllll}
\hline Characters & TL & SL & BD & HL & HD & SnL & LD & LA & LP & CL & CD & ED & BW \\
\hline TL & 1 & & & & & & & & & & & & \\
SL & 0.978 & 1 & & & & & & & & & & & \\
BD & 0.907 & 0.868 & 1 & & & & & & & & & & \\
HL & 0.729 & 0.728 & 0.721 & 1 & & & & & & & & & \\
HD & 0.692 & 0.697 & 0.772 & 0.829 & 1 & & & & & & & & \\
SnL & 0.635 & 0.615 & 0.678 & 0.508 & 0.532 & 1 & & & & & & & \\
LD & 0.852 & 0.831 & 0.815 & 0.669 & 0.615 & 0.391 & 1 & & & & & & \\
LA & 0.943 & 0.914 & 0.849 & 0.715 & 0.700 & 0.525 & 0.775 & 1 & & & & \\
LP & 0.741 & 0.677 & 0.736 & 0.320 & 0.394 & 0.461 & 0.632 & 0.704 & 1 & & & & \\
CL & 0.798 & 0.727 & 0.806 & 0.494 & 0.549 & 0.476 & 0.674 & 0.778 & 0.845 & 1 & & & \\
CD & 0.913 & 0.863 & 0.816 & 0.594 & 0.577 & 0.583 & 0.696 & 0.899 & 0.796 & 0.884 & 1 & & \\
ED & 0.224 & 0.189 & 0.293 & 0.022 & 0.076 & 0.238 & 0.323 & 0.114 & 0.415 & 0.437 & 0.250 & 1 & \\
BW & 0.859 & 0.874 & 0.815 & 0.690 & 0.697 & 0.679 & 0.729 & 0.755 & 0.565 & 0.588 & 0.694 & 0.196 & 1 \\
\hline
\end{tabular}

The closer the r-value to positive $1(+1)$ the stronger the relationship between the features

\section{Length-weight relationship}

The mean total length and body weight of the adult sizes ranged from $20.0 \mathrm{~cm}$ to $26.3 \mathrm{~cm}$ with a mean value of $22.87 \pm 1.44 \mathrm{~cm}$ and $102 \mathrm{~g}$ to $191 \mathrm{~g}$ with a mean weight of $139.70 \pm 25.13 \mathrm{~g}$. The sub-adult sizes ranged from $15.1 \mathrm{~cm}$ to $19.9 \mathrm{~cm}$ total length with a mean value of $17.91 \pm 1.15 \mathrm{~cm}$ and $55 \mathrm{~g}$ to $98 \mathrm{~g}$ body weight with a mean weight of $79.97 \pm 10.23 \mathrm{~g}$. The juvenile sizes, ranged from $10 \mathrm{~cm}$ to $14.9 \mathrm{~cm}$ total length with a mean value of $12.17 \pm 1.68 \mathrm{~cm}$ and $28 \mathrm{~g}$ to $49 \mathrm{~g}$ body weight with mean weight of 
$36.63 \pm 6.20 \mathrm{~g}$ (Table 4). Regression coefficients ' $r$ ' values calculated were $0.85,0.90$ and 0.78 for juveniles, sub-adult and adults respectively. Exponential value of the length-weight relationship ' $b$ ' was $1.03,1.82$ and 2.17 as observed from the above logarithm equations indicating negative allometric growth $(b<3)$.

Table 4: Summary of Length-weight relationship parameters of $\boldsymbol{B}$. macrolepidotus

\begin{tabular}{|c|c|c|c|c|c|c|c|c|}
\hline SIZE & $\mathbf{N}$ & Total Length & & Body Weight & & & & \\
\hline & & Range & Mean & Range & Mean & $\mathbf{a}$ & b & $\mathbf{R}$ \\
\hline ADULT & 60 & $20.0-26.3 \mathrm{~cm}$ & $22.87 \pm 1.44 \mathrm{~cm}$ & $102-191 g$ & $139.70 \pm 25.13 \mathrm{~g}$ & 0.44 & 1.03 & 0.78 \\
\hline SUB-AD & 60 & $15.1-19.9 \mathrm{~cm}$ & $17.91 \pm 1.15 \mathrm{~cm}$ & $55-98 \mathrm{~g}$ & $79.97 \pm 10.23 \mathrm{~g}$ & -0.38 & 1.82 & 0.90 \\
\hline JUVENILE & 60 & $10.0-14.9 \mathrm{~cm}$ & $12.17 \pm 1.68 \mathrm{~cm}$ & $28-49 g$ & $36.63 \pm 6.20 \mathrm{~g}$ & -0.82 & 2.17 & 0.85 \\
\hline
\end{tabular}

\section{Condition factor}

The condition factor $(\mathrm{K})$ values for the three different sizes of $B$. macrolepidotus are $2.17 \pm 0.59,1.39 \pm 0.13$ and $1.16 \pm 0.15$ for the juvenile, sub-adult and adult sizes respectively (Table 5). A significant difference $(\mathrm{p}<0.05)$ was observed between the sizes in all the months.

Table 5: Condition factor of adult, sub-adult and juvenile $B$. macrolepidotus

\begin{tabular}{llll}
\hline MONTH & ADULT & SUB-ADULT & JUVENILE \\
\hline JUNE & $1.26 \pm 0.16^{\mathrm{a}}$ & $1.29 \pm 0.09^{\mathrm{a}}$ & $2.83 \pm 0.13^{\mathrm{a}}$ \\
JULY & $1.19 \pm 0.06^{\mathrm{a}}$ & $1.33 \pm 0.13^{\mathrm{a}}$ & $2.75 \pm 0.17^{\mathrm{a}}$ \\
AUGUST & $1.15 \pm 0.09^{\mathrm{a}}$ & $1.46 \pm 0.07^{\mathrm{b}}$ & $2.35 \pm 0.37^{\mathrm{c}}$ \\
SEPTEMBER & $1.14 \pm 0.10^{\mathrm{a}}$ & $1.53 \pm 0.12^{\mathrm{b}}$ & $1.49 \pm 0.14^{\mathrm{b}}$ \\
OCTOBER & $1.29 \pm 0.23^{\mathrm{a}}$ & $1.45 \pm 0.10^{\mathrm{b}}$ & $1.54 \pm 0.08^{\mathrm{b}}$ \\
NOVEMBER & $1.09 \pm 0.08^{\mathrm{a}}$ & $1.30 \pm 0.03^{\mathrm{a}}$ & $1.92 \pm 0.45^{\mathrm{d}}$ \\
\hline OVERALL & $1.16 \pm 0.15$ & $1.39 \pm 0.13$ & $2.17 \pm 0.59$
\end{tabular}

Mean values with the same superscripts along the columns were not significantly $(\mathrm{P} \geq 0.05)$ different

\section{DISCUSSION}

The morphometric characters showed a proportional positive increase with increase in length of the fish while some showed variations without any relation to length of the fish. In this present study, the length range of $B$. macrolepidotus was in correlation with the study on Brycinus sp. from River Jamieson (Ikomi and Sikoki, 2003) and in Asa reservoir (Saliu, 2002).

However, smaller sizes were reported from the White Volta River (Abobi and Ekau, 2013). Reason for this difference could be due to the geographical location, availability of food and overfishing among others.

Strong positive relationship existed in all the compared features with a few exceptions in all the sizes examined. However, eye diameter (ED) had no correlation with all other traits in the adult samples because it maintained a constant value of 1 irrespective of the length or size of fish. This indicated that increasing length of the fish leads to a corresponding positive increase in other characteristics.

The negative allometry growth pattern $(b<3)$ recorded for all sizes did not corroborate previous studies on the species. Ikomi and Sikoki (2003) reported positive allometry for males and isometric growth pattern for immature Brycinus longipinnis (Günther, 1864) from River Jamieson. Also, Abobi and Ekua (2013) reported higher ' $b$ ' values than that obtained in this study for Brycinus spp: Alestes baremoze (Joannis, 1835), Schilbe intermedius (Ruppell, 1832) and Brycinus nurse (Ruppell, 1832) in the lower reaches of White Volta River. The low values of the length exponential revealed by the species in this study could be due to food availability and state of maturity of the species in this water body, which could be 
due to decrease in preferred food thereby resulting to the weight of the species not aligning with the length as the fish grows. The growth pattern observed in this study is however, in correlation with the findings of Adeosun et al. (2016) who reported that B. macrolepidotus samples collected from this water body showed a negative allometric growth $(b<3)$ pattern.

Condition factor ' $\mathrm{k}$ ' which is an expression of the overall wellbeing of the fish giving information on the physiological state of the fish in relation to its welfare (Gupta and Gupta 2013) was higher than the documented value of 1 for good health and quality fish in all the sizes examined indicating that the species is in good condition in this water body. Ighwela et al. (2011) reported that condition factor has been used as an index of growth and feeding intensity and it decreases with increase in length thus the high condition factor could explain the low value obtained for the length exponent as observed in this study. Also, the lower ' $k$ ' values observed in adult sizes could be attributed to the energy expended by older fish in search of food and prey and also for escaping from being captured by the fishermen and other predators, unlike the juvenile fish that feed on debris, vegetation and insects which require little or no stress. Furthermore, ' $\mathrm{k}$ ' value could also be influenced by biotic and abiotic factors mainly food availability, feeding regime, and the state of gonadal development (Irom et al., 2017). Abowei (2010) and Lizama et al. (2002) confirmed that low ' $\mathrm{k}$ ' values during the reproductive cycle especially when the gonads are well developed might mean transfer of energy to the gonads.

Irom et al. (2017) reported a fall in the condition factor of the species in the months of July to August. This is in correlation with the findings of this study. Highest condition factor of juvenile fish samples occurred in the month of June and reduces afterwards till the end of rainy season (i.e. September). The general reduction in condition factor most especially during the dry season may be attributed to the harsh environmental condition, when there is increase in temperature and reduction in the volume of the water body and other parameters which have been negatively influenced by the season. Braga (1986) showed that values of the condition factor varies according to seasons and are influenced by environmental conditions. Some authors are also of the opinion that extrinsic factors such as temperature and photoperiod affect the quality and condition of fish. The condition factor observed in this study for the species was in agreement with previous studies on the condition factor of this species (Konan et al., 2017; Kamelan et al. 2014). However, Echi and Ezenwaji (2016) and Saliu (2002) reported contrasting findings.

In conclusion, the study examined the morphometric and meristic feature, Length-weight relationship and condition factor of the species in the study location and findings revealed that both morphometric and meristic features could be used for proper identification of the species and could also be used as an indicator of the quality and wellbeing of the species. This study therefore, provides useful information on the growth pattern (LWR) of B. macrolepidotus in this water body.

\section{ACKNOWLEDGEMENT}

The authors acknowledge laboratory technologist in the Department of Aquaculture and Fisheries Management, Federal University of Agriculture, Abeokuta, Nigeria for their assistance during the study. 


\section{REFERENCES}

Abdul, W. O.; Omoniyi, I. T.; Adekoya, E. O.; Adeosun, F. I.; Odulate, D. O.; Idowu, A. A.; Olajide, A. E. and Olowe, O. S. (2016). Length-Weight relationship and condition factor of some commercial fish species in Ogun State coastal estuary, Nigeria. Ife J. Agriculture, 28: 1-10.

Abdul, W.O.; Omoniyi, I.T.; Akegbejo-Samsons, Y.; Agbon, A.A. and Idowu, A.A. (2010). Length-weight relationship and condition factor of cichlid, Sarotherodon galilaeus, in the freshwater ecotype of Ogun estuary, Ogun State, Nigeria. Intl. J. Biol. Chem. Sci., 4: 1153-1162.

Abobi, S.M. and Ekau, W. (2013). Length-weight relationships and condition factors of Alestes baremoze, Brycinus nurse and Schilbe intermedius from the lower reaches of White Volta River (Yapei), Ghana. Intl. J. Fish. Aquacult., 5: 152165.

Abowei, J.F.N. (2010). The Condition Factor, Length-Weight Relationship and abundance of Elops seneganensis (Regan, 1909) from Nkoro River, Niger Delta, Nigeria. Adv. J. Food Sci. Tech., 2: 16-21.

Adeosun, F.I.; Amrevuawho, M. O.; Owolabi, S. A.; Abdul, W. O.; Odulate, D. O. and Idowu, A. A. (2016). Natural diets and length-weight relationship of Brycinus macrolepidotus in Lower Ogun River, Akomoje, Ogun state. Intl. J. Fisheries Aquatic Stud., 4: 139-143.

Anene, A. (2005). Condition factor of four Cichlid species of a Man-made Lake in Imo State, Southeastern Nigeria. Turkish J. Fisheries Aquatic Sci., 3: 43-47.

Ayoade, A.A.; Sowunmi, A.A. and Nwachukwu, H.I. (2004). Gill asymmetry in Labeoo guianensis from Ogun River, Southwest Nigeria. Revista de Biologia Tropical, 52: 171-175.

Bhattacharya, A.K. and Bolaji, G.A. (2010). Fluid flow interactions in Ogun River, Nigeria. Intl. J. Res. Rev. Appl. Sci., 2:173-80.

Braga, F.M.S. (1986). Estudo entre o fator de condição e relação peso/comprimento para alguns peixes marinhos. Revista Brasileira de Biologia, 46: 339-346.

Diayi, M.A. and Gbadebo, A.M. (2014). Pollution assessment of sediment metals from the middle region of the Ogun River, Nigeria. J. Environ. Sci. Water Res., 3: 104-109.

Echi, P.C. and Ezenwaji, H.M.G. (2016). Length-weight relationships and food and feeding habits of some Characids (Osteichthyes: Characidae) from Anambra River, Nigeria. Animal Res. Intl., 13: 2316 - 2320.

Food and Agricultural Organization (1990). FAO Fisheries Synopsis. No. 125: 10. Rome. 442. Gupta SK, Gupta PC (2013). General and Applied Ichthyology: Fish and Fisheries. S. Chand and Company PVT, Limited, Ram Nagar, New Delhi, India.

Ighwela, K.A.; Bin-Ahmed, A. and Abol-Munaf, A.B. (2011). Condition Factor as an Indicator of Growth and Feeding Intensity of Nile Tilapia Fingerlings (Oreochromis niloticus) Feed on Different Levels of Maltose. AmericanEurasian J. Agric. Environ. Sci., 11: 559-563.

Ikomi, R.B and Sikoki, F.D. (2003). Studies on the ecology of the African longfin tetra, Brycinus longipinnis Günther in the Jamieson River (Niger Delta, Nigeria). Acta Ichthyologica et Piscatoria, 33: 17-36

Irom, O.; Offem, B.O. and Keremah, R.I. (2017). Length-Weight Relationship, Condition Factor and Gut Content of Chrysichthys Furcatus Gunther, 1864 (Bagridae) from Cross River at Ahaha. Fisheries Aquac. J., 8: 1-8. 
Kamelan, T.M.; Siaka, B.; Kouamélan, E.P. and N'Douba, V. (2014). Length-weight relationships and condition factor of fish species from Taï National Park Basins, Côte d'Ivoire. J. Biodiv. Environ. Sci., 5: 18-26.

Konan, K.J.; Annigbé, J.E.; Konan, N. and Boua, C.A. (2017). Length-weight relationship and condition factor for 18 fish species from Ono, Kodjoboué and Hébé lagoons, Southeast of Ivory Coast. Intl. J. Fish. Aquat. Stud., 5: 13-18.

Lizama, M.; Delos, A.P. and Ambrosio, A.M. (2002). Condition factor in nine species of fish of the Characidae family in the upper Parana River flood plain, Brazil. Brazilian J. Bio., 62: 113-124.

Moruf, R.O. and Lawal-Are, A.O. (2015). Growth pattern, whorl and girth relationship of the Periwinkle, Tympanotonus fuscatus var radula (Linnaeus, 1758) from a tropical estuarine lagoon, Lagos, Nigeria. Intl. J. Fisheries Aquatic Studies, 3: 111-115.

Ndimele, P.E.; Kumolu-Johnson, C.A.; Aladetohun, N.F. and Ayorinde, O.A. (2010). Length- weight relationship, condition factor and dietary composition of Sarotherodon melanotheron, Rüppell, 1852 (Pisces: Cichlidae) in Ologe Lagoon, Lagos, Nigeria. Agric. Bio. J. North America, 1: 584-590.

Oketola, A.A.; Osibanjo, O.; Ejelonu, B.C.; Oladimeji, Y. B. and Damazio, O.A. (2006). Water quality assessment of river Ogun around the Cattle Market of Isheri, Nigeria. J. Appl. Sci., 6: 511-7.

Olurin, K.B. and Aderibigbe, O.A. (2006). Length-weight relationship and condition factor of pond reared juvenile Oreochromis niloticus. World J. Zool., 1:82-85.

Panase, P. and Mengumphan, K. (2015). Growth performance, length-weight relationship and Condition Factor of Backcross and Reciprocal Hybrid Catfish Reared in net cages. Intl. J. Zool. Res., 11: 57-64.

Paugy, D. (2002). Reproductive strategies of fishes in a tropical temporary stream of the Upper Senegal basin: Baoule River in Mali. Aquatic Living Res., 15: 2535.

Saliu, J.K. (2002). Size, sex and seasonal dynamics in the dietary composition of Brycinus nurse (Pisces: Characidae), from Asa reservoir, Ilorin, Nigeria. Revista De Biologia Tropical, 50: 233-238.

Zar, J.H. (2010). Biostatistical analysis.5th edition. Pearson publishers, New Jersey: Prentice Hall. 